\title{
PENYELESAIAN KREDIT MACETDALAM PERJANJIAN KREDIT DENGAN JAMINAN HAK TANGGUNGAN ATAS TANAH
}

\author{
Sumarni Alam \\ Universitas Islam S yekh-Yusuf, Tangerang \\ salam@unis.ac.id
}

\begin{abstract}
Abstrak
Penulisan "Penyelesaian Kredit Macet Dalam Penyelesaian Kredit Dengan Jaminan Hak Tanggungan Atas Tanah" ini merupakan suatu masalahan yang sering timbul dalam perjanjian kredit antara lain masalah ingkar janji yang berupa keterlambatan pembayaran kredit sebagaimana yang diperjanjikan antara para pihak terkait.Permasalahan yang dikaji dan dibahas dalam penulisan ini adalah bagaimanakah eksekusi dalam penyelesaian kredit macet dalam perjanjian kredit dengan jaminan hak tanggungan atas tanah melalui penjualan bawah tangan dan bagaimana perlindungan bagi kreditor dan debitor dalam hal penjualan asset hak tanggungan atas tanah yang dijadikan jaminan dalam perjanjian kredit.Penulisan ini menunjukkan fungsi jaminan secara yuridis materiil adalah pelunasan hutang atau pengembalian kredit, sehingga apabila terjadi sesuatu yang tidak diinginkan dan terjadi kemacetan dalam pengembalian kredit di kemudian hari, maka secara hukum seharusnya jaminan akan dapat berperan untuk melunasi hutang debitor melalui eksekusi benda jaminan atau pembayaran pihak ketiga. Dalam penyelesaiannya, bahwa pihak kreditor telah melakukan prosedur eksekusi obyek hak tanggungan secara benar dan ideal dengan juga memperhatikan kemampuan debitor dengan memberikan kesempatan dalam restrukturisasi perjanjian dan opsi-opsi lainnya seperti buy bach option dan jaminan yang paling baik adalah tanah, sebagai perlindungan bagi kreditor dalam penjualan yang dibebani hak tanggungan, adapun upaya yang dapat dilakukan oleh kreditor adalah dengan melakukan upaya hukum biasa dengan melakukan penuntutan ganti rugi yang diikuti pula dengan pembatalan penjualan obyek hak tanggungan.
\end{abstract}

Kata kunci : aspek hukum, penyelesaian kredit macet, perjanjian kredit.

\section{A. Pendahuluan}

\section{Latar Belakang}

Bank adalah suatu badan usaha yang menghimpun dana dari masyarakat dalam bentuk simpanan dan menyalurkannya dalam bentuk kredit dan atau dalam bentuk lainnya dalam rangka meningkatkan taraf hidup masyarakat. ${ }^{1}$

Simpanan adalah dana yang dipercayakan oleh masyarakat kepada bank berdasarkan perjanjian penyimpanan dana dalam bentuk giro, deposito, sertifikat deposito, tabungan, dan/atau bentuk lain yang dipersamakan dengan itu.

Dalam sistem perekonomian, perbankan memegang peranan yang penting sehingga sering dikatakan bank merupakan

\footnotetext{
${ }^{1}$ Pasal 1 angka 2Undang-undang Nomor 10 Tahun 1998 tentang Perbankan.
}

jantung dalam sistem keuangan. Bank menerima simpanan dari jutaan orang, pemerintah, dan badan usaha milik negara maupun dari badan-badan usaha swasta. Selanjutnya bank menyediakan dana melalui pemberian pinjaman dan melakukan kegiatan investasi kepada peminjam baik individu, badan usaha maupun pemerintah.

Dalam Pemberian kredit antara bank selaku kreditor dan nasabah selaku debitor dibuat perjanjian terlebih dahulu. Perjanjian adalah suatu peristiwa dimana seorang berjanji kepada seorang lain atau dimana dua orang saling berjanji untuk melaksanakan sesuatu hal. Dari peristiwa ini, timbullah suatu hubungan antara dua orang tersebut yang dinamakan perikatan. Dalam bentuknya, perjanjian berupa suatu rangkaian perkataan yang mengandung 
janji-janji atau kesanggupan yang diucapkan atau ditulis. ${ }^{2}$

Menurut Djuhaendah Hasan yang menamakan perjanjian kredit sebagai suatu perjanjian tidak bernama (onbenoemde overeekomst) dan dasar hukum untuk perjanjian kredit akan berlaku ketentuan pada pasal 1338 Kitab Undang-Undang Hukum Perdata, yang dikenal dengan asas kebebasan berkontrak, yang menyatakan bahwa "semua perjanjian yang dibuat secara sah berlaku sebagai Undang-Undang bagi mereka yang membuatnya". 3

Kredit yang diberikan oleh bank didasarkan pada suatu kepercayaan, sehingga pemberian kredit merupakan pemberian kepercayaan. Unsur dalam pemberian kredit yaitu kepercayaan, waktu, tingkat resiko dan prestasi atau objek kredit dapat dalam bentuk uang ataupun barang.

Dalam Undang-undang Perbankan ditekankan bahwa jaminan pemberian kredit adalah ada keyakinan berdasarkan analisis yang mendalam atas itikad dan kemampuan serta kesanggupan debitor untuk melunasi utangnya, maka bank harus melakukan penilaian seksama terhadap watak, kemampuan, modal agunan dan prospek usaha debitor.

Dalam pemberian kredit oleh bank biasanya bank menginginkan perjanjian dengan adanya jaminan atau agunan. Agunan (jaminan) baik berupa benda bergerak dan tidak bergerak maupun hak atas tanah yang dijadikan jaminan dengan debabani hak tanggungan menurut Undangundang Nomor 4 Tahun 1998 tentang Hak Tanggungan mempunyai fungsi yang sangat kuat bagi kelancaran pinjaman kredit dan merupakan sarana perlindungan bagi kreditur (dalam hal ini bank) dalam

\footnotetext{
2 Subekti, Hukum Perjanjian, Jakarta PT Intermasa 1992, hlm.1

${ }^{3}$ Djuhaendah Hasan, Lembaga Jaminan Kebendaan Bagi Tanah dan Benda Lain Yang Melekat Pada Tanah Dalam Konsepsi Penerapan Asas Pemisahan Horizontal, hlm. 176.
}

kepastian hukum pengembalian dana. ${ }^{4}$ Jaminan adalah suatu tanggungan yang diberikan oleh seorang debitor dan atau pihak ketiga kepada kreditor untuk menjamin kewajibannya dalam suatu perjanjian ataupun perikatan. ${ }^{5}$

Pengertian Hak Tanggungan Atas Tanah Beserta Benda-benda Yang Berkaitan dengan Tanah yang selanjutnya disebut Hak Tanggungan adalah hak jaminan yang dibebankan pada hak atas tanah sebagaimana dimaksud dalam Undang-undang Nomor 5 Tahun 1960 Tentang Peraturan Dasar Pokok-Pokok Agraria, berikut atau tidak berikut bendabenda lain yang merupakan satu kesatuan dengan tanah itu, untuk pelunasan utang tertentu, yang memberikan kedudukan yang diutamakan kepada kreditor tertentu terhadap kreditor-kreditor lain. ${ }^{6}$

Hak tanggungaan memberikan kedudukan yang diutamakan bagi kreditor pemegang hak tanggungan dalam arti bahwa hak tanggungan memberikan kedudukan yang diutamakan kepada kreditor tertentu terhadap kreditor-kreditor lain.

Tetapi dalam prakteknya sering terjadi masalah dalam pemberian kredit salah satunya ialah kredit macet adalah piutang yang sudah jatuh tempo tidak dilunasi dan atau untuk bank terdapat tunggakan pokok dan atau bunga yang melampaui 270 hari, kelangsungan usaha debitor diragukan dan dari segi finansial sudah tidak memenuhi kewajibannya.

Kemampuan dan kesediaan debitor mengembalikan kredit dipengaruhi oleh 6 (enam) macam faktor interen dan eksteren, yaitu : kewenangan hukum mereka meminjam dana, watak mereka, kemampuan mereka menghasilkan

\footnotetext{
4 Pasal 8 Undang-Undang Nomor 10 Tahun 1998 Tentang Perbankan

${ }^{5}$ Pasal 1 angka 23 Undang-undang Nomor 10 Tahun 1998 tentang Perbankan.

${ }^{6}$ Pasal 1 angka 1 Undang-Undang Nomor 4 Tahun 1996 Tentang Hak Tanggungan Atas Tanah Beserta Benda-benda Yang Berkaitan Dengan Tanah.
} 
pendapatan, kondisi fasilitas produksi yang mereka punyai, kondisi dan nilai jaminan kredit yang mereka sediakan, serta perkembangan ekonomi umum dan bidang usaha tempat mereka beroperasi.

Salah satu faktor yang kiranya menjadi menyebab kredit macet adalah besarnya nilai jaminan tidak sebanding dengan pinjaman. Di dunia perbankan pada umumnya dianut konsep penilaian terhadap barang jaminan paling tinggi $80 \%$ dari nilai jaminan, dan besarnya pinjaman dapat diberikan adalah $80 \%$ dari nilai jaminan. Penetapan nilai jaminan atas benda yang akan dijadikan obyek hak tanggungan belum ada acuan yang jelas dan belum memperhitungkan nilai dari hak yang dimiliki oleh seorang pemegang hak, sehingga sanksi terhadap pelanggaran mengenai penetapan nilai jaminan tidak dapat diberikan.

Siswanto Sutojo berpendapat bahwa penyebab kredit bermasalah dapat berhulu pada 3 (tiga) macam sumber faktor, yaitu : faktor internal bank kreditor, ketidak layakan debitor, dan faktor-faktor eksternal. Faktor internal bank yang dapat menjadi penyebab munculnya kredit bermasalah adalah antara lain :

1. Rendahnya kemampuan bank dalam menganalisis kelayakan permintaan kredit yang diajukan oleh debitor;

2. Lemahnya sistem informasi kredit serta sistem pengawasan dan administrasi kredit mereka;

3. Campur tangan yang berlebihan dari para pemegang saham bank dalam keputusan pemberian kredit;

4. Pengikatan jaminan kredit yang kurang sempurna.

Dalam hal debitor sebagai penyebab kredit bermasalah dapat dikelompokkan dalam 2 (dua) kelompok, yaitu perorangan dan perusahaan atau korporasi. ${ }^{8}$

Penjualan hak tanggungan dapat dilakukan dengan cara :

\footnotetext{
${ }^{7}$ Ibid, hlm 18

${ }^{8}$ Ibid, hlm. 20
}

1. Penjualan melalui pelelangan umum;

2. Penjualan di bawah tangan;

Penjualan melalui pelelangan umum berdasarkan Pasal 6 Undang-Undang Hak Tanggungan memberikan kewenangan kepada pemegng hak tanggungan pertama untuk menjual obyek hak tanggungan atas kekuasaan sendiri melalui pelelangan umum serta mengambil pelunasan piutangnya dari hasil penjualan tersebut, apabila debitor cidera janji. Sedangkan penjualan bawah tangan, harus melalui kesepakatan antara pemberi dan pemegang hak tanggungan, penjualan obyek hak tanggungan dapat dilaksanakan di bawah tangan jika cara tersebut akan dapat diperoleh harga tertinggi yang menguntungkan semua pihak.

Berdasarkan uraian diatas, maka permasalahannya adalah bagaimana eksekusi dalam penyelesaian kredit macet dan perlindungan hukum bagi kreditur dalam hal penjualan aset.

\section{B. Pembahasan}

\section{A. Analisis Penyelesaian Kredit macet Dalam Perjanjian Kredit Dengan Jaminan Hak Atas Tanah.}

\section{Eksekusi Penyelesaian Kredit Macet Dalam Perjanjian Kredit}

Suatu masalah yang sering timbul dalam perjanjian kredit adalah masalah ingkar janji. Ingkar janji dalam pemberian kredit dapat berupa keterlambatan pembayaran kredit sebagaimana yang diperjanjikan atau dapat pula dalam bentuk kredit macet. Terhadap keterlambatan pembayaran maupun kredit macet sebagaimana dalam perbuatan ingkar janji selalu ada sanksinya. Dalam kebiasaan perbankan, sanksi bagi keterlambatan pembayaran berupa keharusan membayar bunga tunggakan (sebagai denda), sedangkan terhadap kredit macet, sanksi secara hukum seharusnya dilakukan eksekusi benda obyek jaminan atau pembayaran oleh pihak ketiga. Namun dalam praktek 
perbankan apabila terjadi kredit macet tidak selalu dilakukan eksekusi benda jaminan, karena biasanya bank melakukan usaha-usaha penyelamatan kredit dengan cara lain sebelum akhirnya melaksanakan eksekusi tersebut. Eksekusi benda jaminan di dalam praktek perbankan merupakan upaya terakhir untuk pengembalian kredit yang disalurkan.

Dalam kasus ini, Pihak Kreditor telah memberikan kemudahan kepada ex debitor dengan melakukan restrukturisasi perjanjian merupakan jalan terakhir dilakukan.

Menurut Heru Supraptomo, apabila upaya preventif telah dilakukan, namun kredit yang diberikan menunjukkan adanya gejala kemacetan, maka bank perlu melakukan upaya represif dengan cara penjadwalan kembali, persyaratan kembali, dan penataan kembali. ${ }^{9}$

Bank tidak lagi memberikan kesempatan untuk melakukan restrukturisasi, dikarenakan kondisi tersebut tidak lagi dimungkinkan. Adapun penilaian bank adalah dengan melihat pada indikator prospek usaha ex debitor tidak lagi menjanjikan baik secara kemampuan membayar dikarenakan tidak lagi ada kegiatan bisnis, arus keuangan yang tidak lancar, dan aspek-aspek lainnya.

Sikap pihak kreditor dalam menyikapi kredit macet tersebut adalah melalui prosedur yang benar dan ideal. Sampai pada akhirnya eksekusi atas asset ex debitor harus dilakukan. Dalam pelaksanaan pengeksekusian, terdapat beberapa hal yang harus diperhatikan. Strategi eksekusi wajib juga memperhatikan

\footnotetext{
${ }^{9}$ Heru Soepraptomo, Segi Hukum Penanganan Kredit Macet dan Pengaturan Rahasia Bank. Makalah diskusi BUPLN-Mahkamah Agung, 6-7 Desember 1994, hlm.5
}

daripada itikad baik ex debitor. Tidak semata-mata eksekusi dilakukan dengan melakukan tindakan semenamena oleh pihak kreditor.

Agunan (jaminan) baik berupa benda bergerak dan tidak bergerak maupun hak atas tanah yang dijadikan jaminan dengan dibebani hak tanggungan menurut Undang-Undang Nomor 4 Tahun 1996 tentang Hak Tanggungan mempunyai fungsi yang sangat kuat bagi kelancaran pinjaman kredit dan merupakan sarana perlindungan bagi kreditor (dalam hal ini bank) dalam kepastian hukum pengembalian dana. ${ }^{10}$ Jaminan adalah suatu tanggungan yang diberikan oleh seorang debitor dan atau pihak ketiga kepada kreditor untuk menjamin kewajibannya dalam suatu perjanjian ataupun perikatan. ${ }^{11}$

Secara hukum, sarana pengamanan bagi terlaksananya pengembalian hutang atau kredit adalah adanya jaminan berupa jaminan kebendaan maupun jaminan perorangan. Dalam hal ini jaminan kebendaan masih sangat bermanfaat dan lebih aman daripada menggunakan jaminan perorangan.

Meskipun jaminan perorangan kurang disukai oleh pihak kreditor dan ada beberapa pakar berpendapat kurang bermanfaat, ${ }^{12}$ namun dalam praktek perjanjian ini sering diperjanjikan antara bank dengan pihak ketiga sebagai penanggung yang menurut penilaian bank cukup dipercaya kemampuannya.

Menurut Heru Supratomo, menilai dalam beberapa sarana hukum dalam mempercepat proses

\footnotetext{
${ }^{10}$ Pasal 8 Undang-Undang Nomor 10 Tahun 1998 tentang Perbankan

${ }^{11}$ Pasal 1 angka 23 Undang-Undang Nomor 10 Tahun 1998 Tentang Perbankan.

${ }^{12}$ Subekti, Perjanjian Jaminan dalam Perjanjian Kredit, Alumni Bandung, 1982, hlm 31.
} 
penyelesaian masalah kredit macet yaitu : Pengadilan, Panitia Penyelesaian Piutang Negara, dan Kejaksaan. Dalam hal debitor tidak memenuhi kewajibannya, setiap kreditor dapat mengajukan gugatan untuk memperoleh keputusan pengadilan. Peradilan yang dapat menyelesaikan dan menangani kredit bermasalah yaitu Peradilan Umum melalui gugatan perdata dan Peradilan Niaga melalui gugatan kepailitan. Penyelesaian melalui gugatan perdata biasanya telah sering dilakukan, namun penyelesaian melalui gugatan kepailitan baru dikembangkan kembali setelah terbentuknya peradilan khusus yang disebut Peradilan Niaga.

Prosedur ini memakan waktu relatif lama, oleh karena debitor yang dikalahkan biasanya mengulur waktu dengan mempergunakan upaya banding atau kasasi. Selain itu apabila tetap pengadilan memenangkan gugatan kreditor, kadang-kadang eksekusinya belum tentu membawa hasil yang memuaskan.

Dari segi ekonomi,penyelesaian melalui peradilan ini mengandung kelemahan. Kelemahan tersebut sering terjadi karena beberapa hal, seperti tidak efisiennya sistem peradilan yang ada, sebab harus mengikuti sistem formal dan teknis, sehingga penyelesaian tersebut kurang efektif karena memerlukan biaya yang mahal dan waktu yang lama.

Fakta yang telah terjadi, bahwa telah terjadi kesepakatan para pihak untuk melakukan eksekusi melalui penjualan bawah tangan. Adapun kesepakatan tersebut dilakukan dengan maksud agar ex debitor untuk membantu pihak kreditor guna memudahkan proses eksekusi tersebut. Kesepakatan dalam perjanjian merupakan suatu unsur penting.

Prinsipnya kesepakatan yang dilakukan dalam eksekusi dipandang dapat menguntungkan para pihak dengan cara yang fair (keterbukaan). Menurut ketentuan Pasal 20 ayat (1) Undang-Undang Hak Tanggungan, eksekusi dilakukan berdasarkan $:^{13}$

Apabila debitor cidera janji, maka berdasarkan :

a. Hak pemegang tanggungan sebagaimana dimaksud dalam pasal 6, atau

b. Titel eksekutorial yang terdapat dalam sertifikat Hak Tanggungan sebagaimana dimaksud dalam pasal 14 ayat (2),

Obyek Hak Tanggungan dijual melalui pelelangan umum menurut tata cara yang ditentukan dalam peraturan perundang-undangan untuk pelunasan piutang pemegang Hak Tanggungan dengan hak mendahulu daripada kreditor-kreditor lainnya.

Hak untuk menjual obyek Hak Tanggungan atas kekuasaan sendiri merupakan salah satu perwujudan dari kedudukan diutamakan yang dipunyai oleh pemegang hak tanggungan atau oleh pemegang hak tanggungan pertama dalam hal terdapat lebih dari satu pemegang hak tanggungan (sesuai dengan pasal 6 Undang-undang Hak Tanggungan).

Dalam Hak Tanggungan, hak pemegang Hak Tanggungan untuk melakukan parate eksekusi adalah hak yang diberikan oleh pasal 6 Undangundang Hak Tanggungan. Dengan kata lain, diperjanjikan atau tidak diperjanjikan, hak itu demi hukum dipunyai oleh pemegang Hak Tanggungan.

\footnotetext{
${ }^{13}$ Pasal 20 ayat (1) Undang-Undang Nomor 4 Tahun 1996
} 
Pada prinsipnya setiap eksekusi harus dilakukan melalui pelangan umum, tetapi karena penjualan melalui pelelangan umum tidak selalu menghasilkan harga yang tinggi, maka menyimpang pada prinsip ini. Selain itu dimungkinkan pula melakukan eksekusi melalui penjualan di bawah tangan asalkan syarat-syaratnya dipenuhi, dengan mendapatkan harga penjualan yang lebih tinggi dan menguntungkan semua pihak.

Dengan dicantumkannya secara tegas dalam pasal 20 ayat (2) Undang-undang Hak Tanggungan bahwa penjualan obyek hak tanggungan dapat dilaksanakan di bawah tangan bila ada kesepakatan antara pemberi dan pemegang hak tanggungan, keragu-raguan itu menjadi lenyap.

Suatu kesepakatan dalam eksekusi hak tanggungan melalui bawah tangan, juga harus dipandang sebagai perjanjian pada umumnya. Itikad baik tetap harus dikedepankan. Akibatnya membawa konsekwensi hukum pula bagi si pelanggar.

\section{Perlindungan Bagi Kreditur Dalam Hal Penjualan Asset Hak Tanggungan Oleh Debitor}

Jaminan adalah sarana perlindungan bagi keamanan kreditor yaitu kepastian akan pelunasan hutang debitor atau pelaksanaan prestasi oleh debitor atau penjamin debitor.

Ketentuan pasal 1131 KUHPerdata merupakan jaminan secara umum atau jaminan yang timbul atau lahir dari undang-undang. Disini Undang-undang memberikan perlindungan bagi semua kreditor dalam kedudukan yang sama atau disini berlaku asas paritas creditorium, dimana pembayaran itu pelunasan hutang kepada kreditor dilakukan secara berimbang. Dengan demikian kreditor hanya berkedudukan sebagai kreditor konkuren yang bersaing dalam pemenuhan piutangnya, kecuali ada alasan yang memberikan kedudukan preferen kepada kreditor. $^{14}$

Droit de preference hanya dimiliki oleh para kreditor yang mempunyai hak kebendaan, mengikat perjanjian kebendaan terhadap benda tertentu milik debitor, pengikatan mana yang bersifat hak mutlak atas benda tertentu yang diikat, sehingga apabila debitor cidera janji, maka kreditor mempunyai hak terhadap benda yang diikat untuk mendapat pelunasan terlebih dahulu.

Perlindungan kreditor dalam pemberian kredit merupakan mata rantai kegiatan bank. Langkah pengamanan ini dimulai sejak bankmerencanakan memberikan kredit kepada nasabah. Dalam menyusun memberikan kredit dengan sekaligus plafond, bank telah memperhitungkan berbagai segi dapat dijangkau oleh kemampuan operasional. Mengatur alokasi kredit ke arah sektor yang favourable, diberikan ke nasabahnasabah mana serta dengan jumlah prafond berapa dan sebagainya, merupakan langkah untuk menjaga keamanan kredit.

Perlindungan hukum bagi kreditor yang perlu diberikan adalah dalam kaitannya dengan sita jaminan dan sita eksekutorial terhadap hak atas tanah agar dicatat dalam register Pengadilan Negeri. Hal itu dilakukan untuk menjaga agar kreditor yang lain terhindar dari kesalahan menerima obyek hak tanggungan yang sedang disita yang dapat berakibat pemberian jaminan batal demi hukum.

Menurut pendapat penulis, penjualan obyek hak tanggungan yang telah dilakukan dapat dilakukan. Hal ini dikarenakan debitor telah melanggar ketentuan pasal 1320 ayat (1) Kitab Undang-Undang Hukum Perdata yang melanggar syarat subyektif, akibatnya perjanjian tersebut dapat dibatalkan.

\footnotetext{
${ }^{14}$ Sri Soedewi Masychun Sofwan, Hukum Benda, Liberty, Yogyakarta, 1981, hlm.32
} 
Adapun mengenai tuntutan ganti rugi pula secara bersamaan dengan menjerat pelaku dengan pasal 1365 Kitab UndangUndang Hukum Perdata dengan membuktikan segala bentuk kerugiannya. Selain itu, sebagaimana diungkapkan oleh Yudha Bhakti, bahwa hakim wajib melakukan suatu konstruksi hukum. ${ }^{15}$

Suatu pandangan bahwa kesepakatan dalam perjanjian hak tanggungan secara bawah tangan juga wajib disamakan dengan kesepakatan pada perjanjian pada umumnya. Bentuk kejahatan yang berkembang dalam kehidupan sosial, tetap harus dapat dijerat. Hakim sebagai organ pengadilan dianggap memahami hukum. Dalam metode penafsiran hukum dan konstruksi hukum, hakim dapat menggali dan menemukan apa yang menjadi hukum. Dalam hal ini selama kreditor dapat membuktikan kerugiannya, maka hakim dengan melihat posisi kasus dapat juga memutuskan kepada debitur untuk melakukan pengganti kerugian sebagaimana dituntut padanya.

\section{Kesimpulan dan Saran}

\section{a. Kesimpulan}

1. Dalam penyelesaian eksekusi kredit macet dalam perjanjian kredit untuk hak tanggungan berupa tanah, bahwa fungsi jaminan secara yuridis materiil adalah pelunasan hutang atau pengambilan kredit, sehingga apabila terjadi sesuatu yang tidak diinginkan dan terjadi kemacetan dalam pengembalian kredit di kemudian hari, maka secara hukum seharusnya jaminan akan dapat berperan untuk melunasi hutang debitor melalui eksekusi benda jaminan atau pembayaran pihak ketiga. Dalam kasus yang tercantum, bahwa pihak kreditor secara benar dan ideal dengan juga memperhatikan kemampuan debitor dengan memberikan kesempatan dalam restrukturisasi perjanjian dan opsi-opsi lainnya seperti buy back option.

2. Dalam pemberian kredit dengan jaminan kebendaan, pada umumnya bank selaku kreditor lebih cenderung untuk menerima sebagai jaminan benda yang dibiayai oleh kredit yang diberikan dan jaminan yang paling baik adalah tanah, sebagai perlindungan bagi kreditor dalam penjualan tanah yang dibebani hak tanggungan. Dalam kasus dengan melakukan penuntutan ganti rugi yang diikuti pula dengan pembatalan penjualan obyek hak tanggungan.

\section{b. Saran}

1. Perlu dilakukan kajian dan analisis secara mendalam mengenai jaminan kredit khususnya dalam menyelesaikan masalah kredit macet melalui penjualan bawah tangan.

2. Jaminan merupakan salah satu perlindungan bagi kreditor, namun diharapkan jaminan ini tidak menjadi kendala bagi para pengusaha golongan ekonomi lemah. Perlu adanya perlakuan yang seimbang dalam masalah ini agar kredit yang diprogramkan dapat dilaksanakan merata.

\footnotetext{
${ }^{15}$ Yudha Bhakti, Penafsiran dan Konstruksi Hukum, Alumni Bandung.
} 


\section{Referensi}

Buku-Buku

Amirudin dan H. Zainal Asikin. Pengantar Metode Penelitian Hukum. PT Raja Grafindo Persada, Jakarta, 2004.

Djuhaendah Hasan. Lembaga Jaminan Kebendaan Bagi Tanah dan Benda Lain yang Melekat pada Tanah dalam Konsepsi Penerapan Asas Pemisahan Horizontal.

Eddy Putra Tje'Aman. Kredit Perbankan, Suatu Tinjauan Yuridis, Liberty, Yogyakarta, 1985.

Faisal Affif. Strategi dan Operasional Bank. Eresco, Bandung, 1996.

Garner A. Bryan. Black's Law Dictionary, Seventh Edition.

Imam Saputra. Problematika Hukum Internet Indonesia, PT Prenhalindo, Jakarta, 2002.

Friedman. Laurence M, Legal Theory 5th edition 1967, p.4, dalam Ian McLeod, Legal Theory, (London : Mac Milan Press Ltd, 1998).

Jeremy Bentham, Achmad Ali. Keterpurukan Hukum di Indonesia (Penyebab dan Solusinya), Ghalia Indonesia, tahun 2001.

Kamsir, Bank \& Lembaga Keuangan Lainnya. Edisi keenam, PT Raja Grafindo Persada, Jakarta, 2002.

Mariam Darus Badrulzaman. Perjanjian Kredit Bank, Alumni, Bandung, 1978.

, Perjanjian Baku (Standar) Perkembangannya di Indonesia (kumpulan pidatopidato pengukuhan), Bandung, Alumni, 1981.

, Bab-bab Tentang Hipotik, Bandung. PT Citra Aditya Bakti, 1991.

, K.U.H. Perdata Buku III. Hukum Perikatan Dengan Penjelasan, Alumni, Bandung, 1993.

Mochtar Kusumaatmadja. Konsep-konsep Hukum Dalam Pembangunan, Alumni, Bandung, 2006.

Muhammad Djumhana. Hukum Perbankan di Indonesia. PT Citra Aditya Bakti, Bandung, 1996.

Muchdarsyah Sinungan. Uang dan Bank, Rineka Cipta, 1991. Jakarta, September 1997.

Putra The Aman Edy. Kredit Perbankan Suatu Tinjauan Yuridis, Yogyakarta, Liberty, 1985.

Rachmadi Usman. Aspek-aspek Hukum Perbankan di Indonesia.

Ronny Sautma Hotma Bako. Hubungan Bank dan Nasabah Terhadap Produk Tabungan dan Deposito, Bandung, PT Citra Aditya, 1995.

Roscoe Pound, Tugas Hukum, terjemahan Bharatara, Jakarta, 1956.

Sentosa Sembiring. Hukum Perbankan. Penerbit Mandar Maju, Bandung, 2000.

Siswanto Sutojo. Menangani Kredit Bermasalah. Konsep, Tehnik dan Kasus, PT Gramedia, September 1997.

Smith Adam. Trade and walfare in the World. Harvard University, massattchussets Boston USA, 1956.

Soerjono Soekanto. Pengantar Penelitian Hukum. UI Press, Jakarta, 1986. 
Soerjono Soekanto dan Sri Mamudji. Penelitian Hukum Normatif - Suatu Tinjauan Singkat, PT Raja Grafindo Persada, Jakarta, 2001.

Sri Soedewi Masjchun Sofwan, Hukum Benda. Liberty, Yogyakarta, 1981.

Subekti. Jaminan-jaminan untuk Pemberian Kredit Menurut Hukum Indonesia, Alumni, Bandung, 1982.

, Pokok-pokok Hukum Perdata, PT Intermasa, Jakarta, 1984.

, Hukum Perjanjian, Jakarta, PT Intermasa, 1992.

Sutan Remy Sjahdeni. Kebebasan berkontrak dan perlindungan yang seimbang bagi para pihak dalam perjanjian kredit bank. Jakarta, Institut Bankir Indonesia, 1993.

, Hak Tanggungan, Asas-asas, Ketentuan-ketentuan Pokok dan Masalah yang dihadapi oleh Perbankan (Suatu kajian Mengenai Undang-Undang Hak Tanggungan). Penerbit Alumni, Bandung, 1999.

Thomas Suyatno, et.al. Dasar-dasar Perkreditan. (Jakarta, PT Gramedia Pustaka Utama, 1995).

Thomas Suyatno, H.A. Chalik, Made Sukada, C. Tinon Yunianti Ananda, Djuhaendah T. Marala. Dasar-dasar Perkreditan. Edisi Keempat. PT Gramedia Pustaka Utama, Jakarta 1999.

Yudha Bakti. Penafsiran dan Konstruksi Hukum, Alumni, Bandung.

Yunus Hussein. Kajian Hukum Tentang Rahasia Bank, Tahun 2003.

\section{Makalah Dan Majalah}

Bambang Setijoprodjo, "Referensi dalam Permohonan Kredit", Majalah Pengembangan Perbankan, 1994.

Hasil Penelitian Djuhaendah Hasan, Masalah Jaminan dalam Perjanjian Kredit, BPHN, 1992.

Hasil Penelitian Djuhaendah Hasan, Aspek-aspek Hukum Perjanjian Jaminan dalam Perjanjian Kredit, BPHN, 1993.

Heru Supratomo, "Segi Hukum Penanganan Kredit Macet dan Pengaturan Masalah Rahasia Bank", makalah diskusi panel BUPLN-Mahkamah Agung, Denpasar 6-7 Desember 1994.

Sri Redjeki Hartono. Pengaruh dan Akibat Konsolidasi dan Akuisisi Dalam Upaya Penyehatan Perbankan. Makalah yang dibawakan pada Seminar tentang "Aspek Hukum Merger, Konsolidasi dan Akuisisi dalam Era Globalisasi, diselenggarakan oleh BPHN Departemen Kehakiman, di Jakarta 10-11 September 1997.

\section{Peraturan Perundang-Undangan}

Undang-Undang Dasar 1945.

Undang-Undang Nomor 4 Tahun 1996 tentang Hak Tanggungan Atas Tanah Beserta Bendabenda yang Berkaitan dengan Tanah. 
Undang-Undang Nomor 10 Tahun 1998 Tentang Perbankan.

Kitab Undang-Undang Hukum Perdata.

Kitab Undang-Undang Hukum Pidana

\section{Kamus Hukum}

Black's Law Dictionary, droit de suite dijelaskan sebagai : The right of a creditor to pursue debtor's property in to t a creditor to pursue debtor's property in to the ands of third person for the ands of third person for the enforcemen of his claim 